\title{
EQUAL OPPORTUNITY IN THE SALE OF CONTROLLING SHARES: A REPLY TO PROFESSOR ANDREWS
}

\author{
Grorge B. Javaras $\dagger$
}

I N A RECENT article Professor William D. Andrews has added some novel proposals to the burgeoning discussion of sale of corporate controlling shares at a premium. ${ }^{1}$ It is not the purpose of this short rebuttal to canvass the literature, lest the debate be a reenactment of Jarndyce v. Jarndyce, but rather to question some of Professor Andrews' propositions.

The controversy in this area arises when a controlling shareholder of a corporation disposes of his shares at a premium price unavailable to the other shareholders. Two issues should be kept distinct. First, because the shares entail the power to control the corporation, some restraint is needed to discourage a controlling seller from selling his shares to a person who will harm the corporation. Second, because the non-controlling shareholders are excluded from participating in the premium paid for the controlling shares, they are not given equal treatment.

Professor Andrews' solution follows a rule of equality among shareholders. The controlling seller, if the offer to buy at a premium comprised less than all the shares, would be required to offer to share ratably with the non-controlling shareholders the opportunity to sell the controlling number of shares. The degree to which the non-controlling shareholders accept the offer would determine the controlling shareholders' right to sell more than his pro rata share of the stock desired by the purchaser.

If the controlling seller and purchaser did not tender the offer to the non-controlling shareholders, the latter would be given alternative forms of relief. First, they could compel the seller to purchase from them enough shares at the premium price so that the controlling seller and the non-controlling shareholders would end up holding the same fractional proportion of their holdings as prior to the sale of controlling shares. ${ }^{2}$

$\uparrow$ Fellow in Program for International Organization for Trade and Development, The University of Chicago Law School.

1 Andrews, The Stockholder's Right to Equal Opportunity in the Sale of Shares, 78 HARV. L. REv. 505 (1965).

2 Id. at 552. 
Or, they could sue to compel the purchaser to purchase all their shares at the same price as that paid the controlling seller. ${ }^{3}$

It is Professor Andrews' thesis that this so-called equal opportunity rule would deter sales at a premium to harmful purchasers, without unduly restraining sales to purchasers who would benefit the corporation. ${ }^{4}$ It is argued that harmful sales would be deterred as follows: if the controlling seller wished to dispose of all his holdings at a premium and comply with the rule, he would condition his sale upon an offer by the purchaser for all the corporate shares at the same price so as not to be faced with the specter of liability to the remaining shareholders. Since it would not be profitable for the purchaser to harm the corporation if he owned all the shares, the transaction would not be consummated.

On the other hand, if the controlling seller consented to sell only the pro rata share of his holdings at a premium and apportioned the balance of the offer among the non-controlling shareholders, he also might be deterred from consummating the sale to a harmful purchaser. This retention of stock by the controlling shareholder

will provide the seller with a direct incentive to investigate and evaluate with care when the risks are not apparent, since his own financial interest continues to be at stake. ${ }^{5}$

Professor Andrews contends that the inadequacy of the present rule, which imposes liability on the controlling seller for the premium when he has negligently sold to an irresponsible purchaser, ${ }^{6}$ partially justifies imposing the prophylaxis of the egalitarian rule.

In part the answer is that the kind of harm involved may be extremely difficult to prove or disprove. A transfer of control may have subtle effects that are hard to detect and harder to prove. Employees may leave; morale may suffer; a company may fail to get contracts for which it was being considered. . . . The possibility or likelihood of subtle adverse effects underlies many of the preventive rules of judiciary law. 7

But what are the costs of deterrence in terms of restraining beneficial purchases? Andrews contends they will be slight, since it is his view that the rule of equal treatment will not

3 For Professor Andrews the preferable remedy is that against the seller. $I d$. at 553 .

4 Id. at 519.

$5 \mathrm{Id}$. at 518.

6 See, e.g., Comment, Sales of Corporate Control and the Theory of Overkill, 31 U. CHI. L. REv. 725, 728-39 (1964), for an examination of present law.

7 Andrews, supra note 1, at 518; Jennings, Trading in Corporate Control, 44 Calif. L. REv. 1, 14-19 (1956). 
prevent a purchaser from offering more per share if he acquires control, than if he does not. The rule tends to operate automatically to distinguish between a premium paid for the opportunity of entering into extra stockholder relations [i.e., harming the remaining shareholders], and one that reflects a change in investment appraisal resulting from a shift in control. ${ }^{8}$

How would the rule of equal treatment automatically deter the harmful purchaser of controlling shares and yet not deter the beneficial purchaser? The analysis proceeds by an itemization of possible economic motivations of the purchaser. which would account for his paying a premium for control.

The two basic motivations are: a person who intended to loot the corporation or harm the non-controlling shareholders would not pay a premium for all the shares because he would be only harming himself in his subsequent conduct. Thus, he would only buy controlling shares at a premium. The person, however, who thought that the controlling shares were worth the premium as an investment under his management would be willing to buy all the shares at the premium price. The purchaser's possible lack of funds to pay the premium is met with skepticism. "If he has not sufficient funds of his own to meet a requirement that he bid for all the shares, the requirement does not exclude him from the market; it only requires him to arrange financing."9 Apparently, then, the only beneficial transactions that would be deterred are thought to be those in which the purchaser is denied funds because of the imperfections of the capital market or proper doubts of the lending community.

Professor Andrews advocates his proposed rule not only because it would deter harmful transactions at minimal cost but also because it would promote equality among shareholders in receipt of the premium. He seeks to justify equal treatment on the ground that the non-controlling shareholders are really providing financing for the purchaser; their continued ownership is what makes possible the power of the purchaser to control.10 Because they may have different views as to the competence of the purchaser, he argues, the non-controlling shareholders should have the opportunity to sell their shares at the price received by the seller of control.

Having set forth the Andrews analysis and conclusions, there remains an examination of their significance.

One can agree with Professor Andrews that the rule of equal treatment would probably deter a substantial number of sales of controlling shares

8 Andrews, supra note 1 , at 527 .

$9 \mathrm{Id}$. at 531 .

10 Andrews, supra note 1, at 521 . 
to detrimental purchasers at a premium. The purchaser's alternatives of being required to buy all the shares or being subjected to a more rigorous examination by a seller who will retain some of his shares may well be efficacious. The crucial issue, however, is not how much deterrence will ensue, but rather, how much deterrence of harmful transactions for which the present rule of a seller's liability for negligence is not competent to deal. $I$ have already alluded to the possible difficulty of ascertaining the amount of the harm. Further, under present law it might be that most transfers of controlling shares that are detrimental to non-controlling shareholders are made under conditions where the seller is not negligent, and that in all such cases a reasonable investigation has been made. If this were the case the rule of equal treatment would be desirable on grounds of equity provided the costs of restraining beneficial purchases were not too great. But we do not really know how great is the frequency or magnitude of subtle harm and lack of negligence in the sale to a detrimental purchaser. It is too easy to speculate and attribute to the business community less morality and greater ingenuousness than is the case.

Even the Andrews rule would not forestall all detrimental transfers. It presumes that the great majority of, if not all, detrimental transfers take place at a premium over market value. Although this assumption might be supported by the few reported cases, it may not be accurate. Controlling shares could be sold below market value because rational investors consider the risks of such large interests contrary to their desires to diversify their holdings. ${ }^{11}$ Again, we do not know. ${ }^{12}$ But a complete concern for the possibility of detrimental sales would lead to the conclusion that the equal treatment rule is not enough and that what is needed is a rule that on any sale of controlling shares the purchaser must buy one hundred per cent. The effects of such a rule on deterring beneficial transactions would probably be large indeed.13

Under the proposed rule, one may properly question what happens if it is complied with, only controlling shares are sold at a premium, and the purchaser proceeds to loot the corporation as could have been anticipated by the negligent controlling seller. The non-controlling shareholders may or may not have sold a proportionate part of their shares under the choice given them.

It seems that Professor Andrews would allow no recovery against the negligent seller.

Much of the significance of the rule of equal opportunity, however, is that it does not depend upon proof of harm to the

11 See text accompanying note 20 infra.

12 Hill, The Sale of Controlling Shares, 70 HARv. L. REv. 986, 1038-39 n.150 (1957).

13 See text accompanying note 20 infra. 
corporation. If harm occurs, the rule eliminates the issue of whether the seller could .reasonably have foreseen it. $^{14}$

Since it is not stated why the non-controlling shareholders would not recover against the negligent seller when the rule was complied with, one may only speculate as to possible reasons.

First, as to non-controlling shareholders who elected to sell a portion of their shares to the purchaser at the premium, it might be said that the premium corresponds to the damages and that, therefore, they were fully compensated. But if this assumption were incorrect, it certainly could not be said that any non-controlling shareholder was barred from recovery of actual damages because of his own negligence, even if he anticipated the harm. He had only two alternatives, to sell or not to sell a portion of his shares. By selling he minimized his own losses, because the looting would have occurred in any case; if he had not sold he could certainly have supposed that the controlling seller would have. Indeed, it would be proper to say that even a non-controlling shareholder's knowledge of impending looting should not bar his recovery because nothing he could have done would have prevented the harm.15

And yet the view that the premium corresponds to actual damages, as Professor Andrews seems to believe, ${ }^{16}$ does appear to be erroneous. Even if a looter were able to pay a premium for control and still profit by his looting, why should he pay more than the beneficial purchaser of control? The answer is that he would not, and the premium will not correspond to damages unless most purchasers of control were intent upon doing harm to the non-controlling shareholders. This economic argument has been adequately treated elsewhere, 17 and $I$ am forced to conclude that

14 Andrews, supra note 1, at 518 .

15 A more difficult question is whether a non-controlling shareholder who sold with such knowledge should be liable to a non-controlling shareholder who elected to retain his interest and suffered damages. The same argument can be made that his inaction was not a cause in fact of the damages. I have doubts, however, when I compare the following situation: $\mathbf{P}$ desires control of a publicly-held corporation in order to loot it and therefore makes an offer that if over $51 \%$ of the shares are deposited he will buy them. The shares are deposited, many people purchase and the looting occurs. Does liability of the negligent sellers depend on the fact that they together comprised 51, 25 or $2 \%$ of the shares, or is it their individual holdings that are conclusive?

$16 I d$. at 523.

17 Comment, supra note 6, at 739-44. The argument that a premium paid to loot will differ from that paid by a beneficial purchaser, and that the former will correspond to damages, is analogous to the question in economics as to how a monopolist can keep both markets distinct in order to discriminate in price. If he cannot, purchasers dealing in the higher priced market will buy from the lower. LeFTwich, The Price SYstem and Resource Allocation 216 (1964); Stigler, The Theory of Price 214 (1952).

It must be emphasized that price discrimination is not feasible in a competitive market because the purchasers cannot be separated by just one firm. This fact of diffculty of separation is what compels the conclusion that the premium cannot correspond 
the premium will either over or under compensate the non-controlling shareholders who have sold.

But what of the non-controlling shareholders who have elected not to sell? Is the negligence of the controlling seller to be imputed to them? Or are they to be considered negligent merely by not conducting an independent investigation of the purchaser and his motives and therefore be barred from recovery? I submit that both these possibilities are pernicious given the present status of stockholdings, and I need only parade the horrible of the widow with one share. The proper solution is, instead, to allow an action for actual damages by the non-controlling shareholders against a negligent seller. Whether the premium already received by those who elected to sell a portion should be deducted from actual damages in order to prevent double recovery is dependent upon whether one finds equality itself, as opposed to deterrence of detrimental sales, a sufficient reason for imposing a rule of equal treatment. Under the egalitarian rule one can only piously hope that harm will be deterred.

I believe that the gravest defect in Professor Andrews' theory is a grievous underassessment of the costs of a preventive rule in restraining beneficial transactions. Such restraint would operate on the purchaser by imposing higher required investment-the price of all the shares of the corporation rather than only those owned by the controlling shareholder. Professor Andrews minimizes the effects of this factor on two grounds. First, the controlling shareholder under the rule of equal opportunity, when confronted with a purchaser who wants the controlling shares and no more, may be induced to retain some of his shares and share the sale ratably with the non-controlling shareholders. Admittedly, this requires faith in the management of the purchaser. Second, a beneficial purchaser should be willing to buy all the shares because, after all, the non-controlling shares have the same investment value as the controlling shares. All the purchaser would have to do, therefore, if he did not have the capital is to borrow it. ${ }^{18}$ If he could not, that would be a reflection either of superior knowledge in the financial community or dislocations in the capital market.

It is doubtful whether sufficient controlling sellers can be induced to retain their shares so as to eliminate the higher capital requirement. First, as pointed out by Professor Stigler in his recent assessment of the work of the Securities and Exchange Commission, ${ }^{19}$ sales of securities are not dictated merely by an appraisal of investment value. Many sellers simply

to damages unless a very large proportion of the purchasers intend to harm the remaining shareholders.

18 Andrews, supra note 1 , at 519.

19 Stigler, Public Regulation of the Securities Markets, 37 J. Bus. 117 (1964). 
want immediate cash. Second, a controlling seller may not wish to hold, say twenty-five per cent as compared to his prior fifty per cent, because of the possibility of his views differing from those of the controlling purchaser in the future. This reticence would partly stem from the politics of large shareholdings for which judicial intervention is not only ineffective but undesirable. But it would also arise from the controlling sellers assessment of the change in risks when he is deprived of control. The loss of control would subject him to the risk of poor management, which might dictate a lesser investment in this corporation on the principle of risk diversification. ${ }^{20}$

Likewise the purchaser himself might be unwilling that the seller retain some of his shares, particularly where working control (less than fifty per cent) is the subject of the offer. He might well be reluctant to have a large block of stock outstanding whose owners, under conditions of dissension, could mobilize the other shareholders and displace his control of the board of directors.

In effect then, the rule of equal treatment would impose higher capital requirements on beneficial purchasers in a substantial number of transactions: Professor Andrews inappropriately assumes, however, that the purchasers should be willing to meet these higher costs because the investment value of the additional shares is the same. He errs in that his reasoning is incomplete. It is true that the investment value is the same. But even if the capital market did function perfectly and the purchaser could arrange the financing, a rational businessman might not want to buy all the shares at a premium price justified by the investment potential. It might be sensible to decline to buy more than the bare amount necessary for control on the principles of diversification of risk and of opportunity. This might render the equal treatment rule ineffectual as a means of automatically distinguishing "good" and "bad" purchasers. I would think that the number of prospective beneficial purchasers prevented because of a desire to diversify will be much larger than those simply unable to raise the capital. Until empirical evidence is adduced to the contrary, I am predisposed to consider this cost of restraining beneficial transactions substantial when compared with the cases of detriment with which the present law is incompetent to deal.

Nor does the fact that the remaining non-controlling shareholders bear the burden of financing the purchaser stand as an alternative ground to justify the equal treatment rule. Of course, they provide financing but the argument proves too much. At its extreme it would justify an

20 See Muscrave, The Theory of Public Finance 313-18 (1959), for an excellent theoretical description of the principle of risk diversification in a different contextthe effect of taxation on investment portfolios. 
apportionment of managerial salaries paid to the purchaser. Professor Andrews, in fact, seems to use the financing argument as an alternative to stating that it is fair for them to share in the premium because they are taking a portion of the risks. ${ }^{21}$ If this is what is meant, then one might demur that unlike the selling shareholder, they will be receiving benefits from the better management.

Apparently, even Professor Andrews is not swayed by the financing argument because he rejects it in a similar situation. In a corporate recapitalization when a single class of common stock replaces two classes which are identical except that one has voting rights, the issue is whether a premium for control should be allowed to the voting shares. ${ }^{22}$ Professor Andrews reasons as follows:

The problem of the relation of voting to non-voting stock is a thorny one. Many of the reasons for the rule of equal opportunity would seem to require that holders of non-voting shares be given an equal opportunity to sell if the controlling insiders sell their voting stock. In particular, even within the context of a recapitalization, the analogy to corporate action by way of sale of assets and subsequent liquidation would seem to call for equal treatment. But the rule of equal opportunity presupposes fungible securities to be offered for sale. Voting and non-voting stock are not fungible.[Quaere?] And a voting stockholder does not enjoy his power of control by exercising it to bring about the recapitalization, as a controlling shareholder does when he brings about a sale to outsiders, because he gets nothing by way of change in investment from the transaction. Unless he is permitted some premium for relinquishing sole voting power, the owner of voting stock in a two-class situation would often have no reason to give it up. ${ }^{23}$

Professor Andrews reaches this conclusion in spite of the fact that because of the premium the non-voting shareholders are financing the recapitalization. How can this premium be distinguished from that arising from the sale of corporate controlling shares? It cannot be because a recapitalization eliminating non-voting shares is always beneficial, because this is to place too much emphasis on balance sheet legerdemain and the desirability of listing on the New York Stock Exchange, which is unavailable with non-voting common stock. Nor can it be because the the non-voting shareholders as a class have the opportunity to reject the recapitalization. Unlike the proposed rule for sale of controlling shares, the dissidents in a recapitalization cannot elect to be bought out. Their

21 Andrews, supra note I, at 521.

22 See, e.g., Honigman v. Green Giant Co., 309 F.2d 667 (8th Cir. 1962).

23 Andrews, supra note 1 , at 560 . 
appraisal rights are not triggered by a recapitalization, ${ }^{24}$ nor are they offered an opportunity to share in the premium. Indeed the probabilities of harm and benefit seem generally indistinguishable from cases of sale of control except in one respect. In a recapitalization the premium fixes the maximum damages-the voting shareholder is not expected to loot the corporation afterward. This fact of lesser magnitude of risks reinforces my previous opinion that the financing argument is just a shorthand for saying that it is fair to pay the non-controlling shareholders for taking the risk of management by the new controlling shareholder. If this is so, the protection against detrimental sales at a premium coupled with the possibility of a beneficial purchase should be sufficient.

Aside from the elegance of the ideal, which $I$ leave to commentators on reapportionment, it seems that "equality" can only be justified if it somehow improves the functioning of the securities market. Admittedly it might restrain detrimental transactions, but at great cost. It might on the other hand be contended that equality would so improve the psychology and faith of investors, as the securities acts are alleged to do, that all present shareholders would be benefited by the influx of new shareholders. But it is proper to note in closing that in corporation law it is the maximization of profits that is the overriding principle, and unlike the political arena, equality is not justified for its own sake.

24. See, e.g., MinN. StAT. ANN. § 301.40(1) (1947). 